fascism and the maze of its domestic policy, as well as the cultural and political history of Italy and Europe.

\title{
ANGELO PRINCIPE
}

(Toronto)

Claudio Fogu. The Historic Imaginary: Politics of History in Fascist Italy. Toronto Buffalo London: University of Toronto Press, 2003. Pp. x, 288 ISBN 0802087647. \$65 CND (cloth).

Claudio Fogu's book is a very interesting addition to the corpus of cultural studies on the politics of culture and history in fascist Italy. The main purpose of this volume is to study the "fascist politics of history in 1920s and 1930s Italy in order to show the centrality of this field of cultural production to the formation and evolution of a fascist-modernist mass culture" (6-7). Fogu defines the "politics of history," as "the vision of the relationship between historical agency, representation, and consciousness elaborated by fascist ideologists, and its institutionalization into mental, discursive, and visual images designed for mass consumption" (7). This conceptualization shows the necessity of bringing together a variety of disciplines, such as history, philosophy, anthropology, and to some extent literature, in order to understand Mussolini's vision and his wish to reshape not only Italy but, indeed, Italians during his dictatorship. Such a conceptualization is the key to understanding the dictator's legacy to a country still in formation as well as his legacy to Italians still trying to understand their role in the newly unified nation after the Risorgimento.

At the core of Fogu's study is the construction of a fascist imaginary in its complex array of images and words. Museums, exhibitions, and archives are among the favourite sites of research Fogu deems appropriate for defining the connections between the politics of history and the construction of such a collective imaginary in which the visual played an extraordinary role. Fogu argues convincingly that Fascism, as a "historic agent" that conflates the concepts of history and historiography, appears reified in Giovanni Gentile's theory of Fascism. Gentile's reformulations of actualism constitute a theory that, according to Fogu, intellectualizes Mussolini's sense of politics and history as encapsulated in the dictator's famous motto: "Fascism makes history; it does not write it."

This is an ambitious volume whose purpose is to tie Mussolini's genuine interest in the arts to a higher ideology (in an intellectual sense). The Duce's effort, joined in this by his entourage of intellectuals, was geared toward the pragmatic construction of a mentality that would bring conformity to the average Italian by utilizing some of the "higher" criteria for a more available system of ethics and aesthetics. With this in mind, a collective imaginary would be created for the Italian population, and this would happen regardless of geographical differences. Within such a horizon, Fascism would constitute the key to understanding the present.

In this text, fascist ideology is thus perceived as an indispensable tool for 
rereading the recent past, namely the Risorgimento, as well as antiquity, that is Rome and its empire. Also, the relationship between such a varied "past" to history in the making, which Mussolini so strongly promulgated, was an important element of that imaginary. History and theory are at the core of Fogu's work almost per force, as one implies the other, since his aim is the construction of what he calls a "poetics of history underlying fascist ideology."

Connecting the ideologists of the fascist aesthetic to the theory of history, Fogu draws differences between Nazi and fascist politics of history, and in doing so, successfully demonstrates how their scope was entirely different. According to the author, Nazi politics was projected towards the future and, as a result, imposed normative notions on what Nazi art should be, namely, a tool for the implementation of the regime. In the case of the fascists, the emphasis was on the past. The events of the previous centuries thus became a unifying factor in which art had the mandate of giving style to the Italian masses, while glorifying history in the making (23). Fogu states that, "fascism celebrated its historicness by institutionalizing a historic mode of representation at all levels of visual and ritual mass culture" (10). Further, he clarifies how, "the institutionalization of fascist historic culture led to, and was sustained by, the formation of a collective historic imaginary that was at the root of fascism's mass appeal and the intellectual challenge that observers, such as Bataille, recognized in the fascist politics of history" (10).

Chapters One and Two, "History Belongs to the Present" (21-51) and "Il Duce Taumaturgo" (52-71), are devoted to explaining the rise of Mussolini's theorization of history as present, as "process-in-the-making." Mussolini's closeness to avant-garde groups certainly ignited his spirit; the influence can be seen in his conceptualization of the identity of art and politics. This union of art and the state followed his cultural politics throughout his entire dictatorship and contributed to his own rise. Critica fascista, the intellectual review, was Mussolini's chief information medium for bringing artistic and other intellectual forces into his debate on the most efficient means for expressing his aesthetic creed (22). Fogu performs a very interesting reading of both how Fascism saw the Risorgimento and how Giovanni Gentile, the Duce's philosopher, contributed to revisiting the legacy of one of the leaders of Risorgimento, Giuseppe Mazzini. In Gentile's writings, in fact, Mazzini becomes an anticipator of Fascism. The thinker's elaboration of his philosophy on actualism served as the basis for this newly formed image of Mazzini (27). Gioacchino Volpe's subsequent Litalia in cammino is another step towards the theorization of a "fascist's social integration of the Italian masses, but in a state built up by the liberal leadership" (29). In all his speeches Mussolini attempted to "simultaneously enact and historicize a modernist form of mass consciousness in which language and force had abandoned the realm of historical crisis and entered that of historic eventfulness" (35). Chapter one continues with a more expansive analysis of Gentile's elaboration of actualism in his 1912 essay, "Latto del pensare come atto puro."

Chapter two analyzes the ways in which the regime sought to "exorcise" the trauma of war, a process that the fascists quickly managed to organize around the veterans' sufferings. Fogu underscores the central role of Antonio Monti, head 
archivist and curator of the Museo del Risorgimento in Milan, in the construction of a public image for Mussolini as a saviour of the WWI veterans and, by extension, of all Italians. The dictator was to be perceived as the "Man of Providence," sent by God to accomplish what was left undone by the Risorgimento. Far from being depicted as they are in Otto Dix's horrifying representations of prosthetics, the war wounded are transfigured into "recipient(s) of Mussolini's thaumaturgic touch" (54). Mussolini is depicted as a remedy, then, to the injustice of "bourgeois hypocrisy." The dictator becomes the leitmotiv of propaganda and the myth of "Mussolini," or mussolinismo as "fascism's autonomous double" (56) is born. Celebrations of the march on Rome are held every year to mark the "emergence of a historic agent in history" (55). The public image Monti constructs for Mussolini appears thus to be fundamental to the passage from a spontaneous fascination with the man, mussolinismo, to the artfully constructed cult of the Duce, ducismo, for, as Fogu points out, Monti's Duce Taumaturgo represents the fascist hypericon, "an image that speaks of the nature of historical representation during fascism" (57), or something of a metaphor for the whole, as this image captures the essence of the whole.

Monti was also essential to the revision of the Risorgimento via his clear vision of the way Risorgimento museums should be, that is, the criteria to be used for their collections and expositions. He carefully revised the frame within which visitors would understand the historical recent past and connect with the Duce's rise to power (63-65). The Risorgimento was not a disaster, certainly, but something incomplete that awaited the Duce to bring about its completion and an age of splendour. The true unification of Italy was in fact to be carried out by Fascism, and Mussolini in particular. According to Fogu, this epochal fusion of the Risorgimento and the Great War did not take place. In fact, this lack of what the museotechnocrat Monti hoped for shows a larger psychological Lacanian "lack" in the Italian collectivity; that is, the failure to absorb the traumatic events whose consequences were so apparent in German art.

Chapter three, "The Historic Spectacle," deals with the celebrations of the Garibaldi jubilee (72-95). The introduction to mass media is marked by Mussolini's speech of June 4, 1932. This speech, which concluded the celebrations with the unveiling of Anita Garibaldi's monument, was an eloquent complement to the Roman parade, a complex apparatus of the fascist spectacle which, the author holds, makes clear how such a celebratory event was "to represent the constitution of fascism as a bistoric agent" under whose rhetorical umbrella the Garibaldian past was reconceived in terms of the present history-in-the-making.

In Chapter four, "The Historic Imaginary and the Mass Media" (96-113), Fogu shows how the "transfiguration" of the celebrazioni garibaldine became possible thanks to a powerfully orchestrated series of events conceived largely for a "mass media reproduction" (97). Many factors account for such a transfiguration, among which are the invitation of seventy-five journalists to Mussolini’s inaugural speech and the speech itself. Fogu provides a significant appendix in which texts from forty-five newspapers appear. The author also discusses the important role that the occasion had in the productions of LUCE, in the form of three newsreels 
and two documentaries (105-13). Fogu notes how, " $[\mathrm{t}]$ he appearance of LUCE operators at every commemorative event thus announced the presence of a powerful rival that no newspapers could ignore, especially because of the novelty of sound film" (105).

More importantly, the spectacle of the cinquantenario is linked to that of the decennale fascista, ultimately marking the ideal point where the gap between the figure of Garibaldi and that of Mussolini is bridged. The Mostra garibaldina and the Mostra della rivoluzione fascista are parallel in their importance for the "institutionalization of fascist historic culture" (113).

In Chapter five, "The Context of the Exhibitions" (114-64) we find a complete rendering of the exhibitions that took place during Mussolini's dictatorship. Following the relatively brief tradition of the World's Fairs in Turin and Rome, the didactic intent of these exhibitions was apparent to the public and conveyed a clear sense of Mussolini's beliefs, particularly in the light of Italy's recent entry on the imperialistic map.

In the sixth chapter, "Fascist Historic Culture' (164-89) Fogu analyzes the various fascist exhibitions. However, supported by Gentile's actualist vision of history, "the fascist historic imaginary had not remained faithful to any of its original traits" (196), resulting in the severing of the connection Mussolini envisioned between his own myth and that of the fascist imaginary. The museification of the past and present was probably the most evident cause for the lack of this hopedfor connection. As Fogu states, "contrary to Gentile's prediction [...] the fascist mind had reoriented itself from history belonging to the past to history into the future with the advent of stile littorio against fascist modernism" (197). Also, and more importantly, the failure to reach Mussolini's goals was due to the previous failure of the post-Risorgimento era to nationalize the Italian masses.

In conclusion, Fogu's theoretical and pragmatic approach to the study of fascist culture linked with a poetics of history, is a new way of looking at Fascism and its attempt to construct a collective imaginary based on present history, while starting from a very diversified past. Rich in sources and original in its approach, this study is a brilliant reconsideration of fascist culture from a different and unbiased angle. Fogu's thesis is interesting as is his elaborate commentary on the artistic productions for the masses that Fascism managed to generate in twenty years of Italian history. These are not many, if one thinks of the history of our country but sufficient to spark debates, the traces of which are still visible in the Italian present collective imaginary. This is not a revisionist book in terms of "normalizing" the fascist years. It is not the author's intent, I believe. Fogu's objective is, instead, to diversify and make more complex an intellectual panorama that we see treated sometimes in ways that too easily discuss that panorama in almost structuralistic terms, as if binary oppositions could suffice to draw the map of Fascism. 